\title{
ROBERT FRANKLIN MUIRHEAD, B.A., D.Sc.
}

\author{
By John Dougall.
}

Robert Fraxklin Muirhead was born at Shawlands, Glasgow, in January 1860. From 1868 to 1872 he was educated under tutors at his father's home, Meikle Cloak, near Lochwinnoch, and at the village school. He was at Hamilton Academy in 1872-73, and at Paisley Grammar School in 1873-75 (dux, 1875). From 1876 to 1881 he studied at Glasgow University. He graduated as M.A., B.Sc., with highest honours in Mathematics and Natural Philosophy, and gained the Ferguson Scholarship.

With the George A. Clark Scholarship from Glasgow he went up to Cambridge, to St Catharine's College. He was nineteenth wrangler in 1884, was classed Division I, Part III, in 1885, and was awarded a Smith's Prize in 1886 for an essay on Newton's Laws of Motion.

During his four years tenure of the George A. Clark Scholarship he conducted supplementary classes at Glasgow University both for pass and for honours men. The present writer well remembers his lectures at this period on Theory of Equations, and on Electrostatics, and can vouch for the high quality of his teaching of these subjects. The friendship thus formed continued unbroken throughout Muirhead's life. A truer and more helpful friend no one could possibly have.

About 1885 he went to Germany and spent a year at Göttingen University where he attended the lectures of Schwartz. The next few years were spent in teaching work of various lkinds and at various places-Mason College, Birmingham, Keith and Edinburgh. Characteristically the first school to which he was attracted was one founded by Dr Reddy at Abbotsholme, the special feature of which was the absence of all corporal punishment. Muirhead had a rooted aversion to compulsion of any kind-an "anarchist" was what he used to call himself.

He married in 1893 and soon afterwards settled down in Glasgow as a coach in Mathematics, Physics and Engineering. His classes were very successful, and those in Mathematics were recognised under the University extra-mural scheme as qualifying a student to sit his degree examinations. About forty years ago he founded the Glasgow Tutorial College, which he continued to supervise almost up to the time of his death. 
Muirhead published many papers on mathematical subjects, most of them in our own Proceedings and Mathematical Notes, and in the Mathematical Gazette. The topics were mainly elementary-for example, he gave a large number of proofs of the Binomial Theorem for a positive integral index. Among longer papers may be mentioned "On the number and nature of the solutions of the Apollonian contact problem" in Vol. 14 of our Proceedings; and "On a method of studying displacement" in Vol. 15. Akin to the latter paper was one on the Foundations of Geometry read at the International Congress at Cambridge in 1912 .

He also wrote a number of papers on Inequalities, notably one on "Inequalities relating to some algebraic means" (Vol. 19). Prof. G. H. Hardy, in a lecture on the Theorem of the Arithmetic and Geometric Means, has directed attention to some very important but much neglected work by Dr R. F. Muirhead on inequalities of a more general type.

Muirhead took a deep interest in the Edinburgh Mathematical Society. He was elected a member in its second session, in February 1884. He became President in 1899, and again in 1909; and was elected an Honorary Member in 1912.

He was a keen politician, with a strong bias towards the left wing, especially in his youth. One of his most intimate friends was Edward Carpenter, author of "Civilization: Its Cause and Cure." When the Russian " nihilist," Prince Kropotkin, held a meeting in Glasgow, about 1895, Muirhead was his chairman. He had an idea that it might have been better for his professional career had his political sympathies been more orthodox, or less outspoken. In later years he was a prominent supporter of the movement for Scottish Home Rule.

His social sympathies were by no means merely theoretical. His helping hand had a wide reach, though you had to know him well to find it out.

Dr Muirhead's wife, who was an accomplished musician, died last year. They leave a family of two sons and two daughters. 